Original Research Article

\title{
Monitoring effects of atenolol versus olmesartan medoxomil on metabolic parameters
}

\author{
Ranjodh Jeet Singh ${ }^{1}$, Kanika Kohli ${ }^{2 *}$, Parveen Gupta ${ }^{3}$, Ashwani Kumar Gupta ${ }^{1}$
}

\begin{abstract}
${ }^{1}$ Department of Pharmacology, ${ }^{2}$ Department of Forensic Medicine, ${ }^{3}$ Department of General Medicine, Maharishi Markandeshwar Institute of Medical Sciences and Research, Mullana, Ambala, Haryana, India
\end{abstract}

Received: 13 July 2018 Accepted: 11 August 2018

*Correspondence to:

Dr. Kanika Kohli, Email: kohlikanika1986@ gmail.com

Copyright: (C) the author(s), publisher and licensee Medip Academy. This is an openaccess article distributed under the terms of the Creative Commons Attribution NonCommercial License, which permits unrestricted noncommercial use, distribution, and reproduction in any medium, provided the original work is properly cited.

\begin{abstract}
Background: The increase in CVS morbidity and mortality could be significantly reduced by control of SBP and DBP, as well as reduction in Hyperlipidemia.
\end{abstract}

Methods: The patients of stage-1 HTN with either sex according to JNC VII criteria were included and were followed up every 2 weeks from baseline upto 12 weeks. The randomized patients were divided into two groups to receive beta blocker viz. Atenolol $50 \mathrm{mg}$ (group A, N=50) and ARB Olmesartan medoxomil 40 mg (group B, N=50).

Results: The average Total cholesterol measured among Group A subjects was significantly increased by $1.8 \%$ by the end of 12 th week whereas the average cholesterol measured among Group B subjects at baseline period was reduced by 7.9\% after 12 weeks therapy. The average HDL measured among Group A subjects at baseline period significantly reduces by $5.9 \%$ by the end of 12 th week whereas the HDL levels measured among Group B subjects at baseline period was significantly increased by after 12 weeks therapy. The average Triglyceride (TG) levels measured among Group A subjects at baseline period was significantly increased by $12.4 \%$ by the end of 12 th week whereas the Triglyceride (TG) levels measured among Group B subjects at baseline period was significantly reduced by $9.5 \%$ after 12 weeks therapy. The average LDL levels measured among Group A subjects at baseline period was significantly increased by $1.5 \%$ by the end of 12 thweek whereas the average LDL measured among Group B subjects at baseline period was significantly reduced by $11.2 \%$ to after 12 weeks therapy. The average VLDL levels measured among Group A subjects at baseline period was significantly increased by $12.4 \%$ by the end of 12th week whereas the average VLDL measured among Group B subjects at baseline period was significantly reduced by $9.5 \%$ after 12 weeks therapy.

Conclusions: ARB- Olmesartan medoxomil is a better drug than beta blockerAtenolol as it leads to greater deduction in lipid profile.

Keywords: Atenolol, CVD, COPD, DBP, HCTZ, HTN, Stage-1 HTN

\section{INTRODUCTION}

Throughout the world, including India, the cardiovascular disorders are the most common cause of mortality and morbidity of patients. ${ }^{1}$ Among the various cardiovascular disorders, Hyperlipidemia contributes to one of the most common risk factor for cardiovascular disorders, the treatment of which leads to significant reduction in cardiovascular mortality and morbidity. ${ }^{2}$ According to JNC VII, term HTN is defined as SBP of 140/90mmhg or more on two occasions measured apart weekly. The prevalence of HTN increases with advancing age, about $50 \%$ of people between ages of 60 and 69 years have HTN, and prevalence is increased beyond age of 70 years. ${ }^{3}$ It affects approximately one-third of world's adult population and is predicted to increase with $60 \%$ towards 
$2025 .^{4}$ It is also associated with number of serious conditions and for $13.5 \%$ of premature deaths, $54 \%$ all strokes and $47 \%$ of ischemic heart diseases. ${ }^{5}$

According to Joint National Committee (JNC) 7 report HTN can be classified as:

1. Primary (essential) hypertension - with no obvious underlying medical cause, it results from complex interactions between multiple genetic and environmental factors, accounts for $90-95 \%$ of cases.

2. Secondary HTN with identifiable cause revealed by history, physical examination and routine laboratory tests that might be affecting kidneys, arteries, heart or endocrine system. ${ }^{3}$

3. JNC VII.

Table 1: Various study group with their diagnostic blood pressure.

\begin{tabular}{|c|c|c|c|}
\hline Category & $\begin{array}{l}\text { Systolic } \\
\text { mmHg }\end{array}$ & & $\begin{array}{l}\text { Diastolic } \\
\text { mmHg }\end{array}$ \\
\hline Normal & $\leq 120$ & And & $\leq 80$ \\
\hline Pre-hypertensive & $120-139$ & Or & $80-89$ \\
\hline \multicolumn{4}{|l|}{ High BP } \\
\hline Stage 1 & $140-159$ & Or & $90-99$ \\
\hline Stage 2 & $\geq 160$ & Or & $\geq 100$ \\
\hline
\end{tabular}

Cardiovascular diseases caused 2.3 million deaths in India in the year 1990; this is projected to double by the year 2020. Hypertension is directly responsible for $57 \%$ of all stroke deaths and $24 \%$ of all coronary heart disease deaths in India. ${ }^{7}$ However, JNC VIII has been released as new classification for treatment of HTN. ${ }^{8}$

\section{METHODS}

The present study was conducted to determine the efficacy and safety of drug with respect to more reduction in metabolic parameters. A randomized, prospective, open parallel group study for 12 weeks duration was conducted by Department of Pharmacology in collaboration with Department of general Medicine at outpatient department of Medicine, M.M.I.M.S.R, Mullana. The protocol for study was approved before commencement by Institutional Ethics Committee.

\section{Inclusion criteria}

- The Patients of either sex with Stage-1 HTN

- Aged between 18-60 years

And they were followed up every 2 weeks from the baseline upto 12 weeks. $^{3}$ The Patients were divided randomly into two groups to receive Tab Atenolol 50mg OD orally (Group A, N=50) and Tab Olmesartan medoxomil 20mg OD orally (Group B, N=50). The Patients with stage I HTN as per inclusion and exclusion criteria \& documented informed consent were included.

\section{Exclusion criteria}

- The Patients of secondary HTN

- On other antihypertensive therapy

- Pregnant/lactating.

The Clinical examination of all patients was done by measurement of BP before administration of drug therapy. The response to study treatments was evaluated in terms of effects on metabolic parameters and BP.

\section{Statistical analysis}

The results were analysed using Student ' $t$ ' test (paired and unpaired Students ' $t$ ' test) using computer software - SPSS version 16.0. $\mathrm{P}$-value $<0.05$ was considered as significant.

\section{RESULTS}

In demographic baseline parameters no significant changes, viz sex and age in both the groups.

Table 2: Comparison of total cholesterol levels of subjects in group A and group B.

\begin{tabular}{|c|c|c|c|c|c|}
\hline & \multicolumn{2}{|c|}{ Atenolol 50mg (group A) } & \multicolumn{2}{|c|}{ Olmesartan 20mg (group B) } & \multirow{2}{*}{$\begin{array}{l}\text { T- Test } \\
\text { (p- value in b/w groups) }\end{array}$} \\
\hline & Mean \pm SD & Paired T- Test p-value & Mean \pm SD & Paired T- Test p-value & \\
\hline Baseline & $213.7 \pm 20.7$ & \multirow{2}{*}{$<0.05$} & $211.4 \pm 20.8$ & \multirow{2}{*}{$<0.05$} & $>0.05$ \\
\hline Week 12 & $217.5 \pm 18.5$ & & $194.6 \pm 12.6$ & & $<0.05$ \\
\hline$\%$ Change & 1.8 & & -7.9 & & \\
\hline
\end{tabular}

Table 3: Comparison of High Density Lipoprotein level of subjects group A and group B.

\begin{tabular}{|c|c|c|c|c|c|}
\hline & \multicolumn{2}{|c|}{ Atenolol 50mg (Group A) } & \multicolumn{2}{|c|}{ Olmesartan 20mg (Group B) } & \multirow{2}{*}{$\begin{array}{l}\text { T- Test } \\
\text { (p- value in b/w groups) }\end{array}$} \\
\hline & Mean \pm SD & Paired T- Test p-value & Mean \pm SD & Paired T- Test p-value & \\
\hline Baseline & $39.9 \pm 7.8$ & \multirow{2}{*}{$<0.05$} & $39.6 \pm 7.9$ & \multirow{2}{*}{$<0.05$} & $>0.05$ \\
\hline Week 12 & $37.6 \pm 6.7$ & & $41.5 \pm 7.2$ & & $<0.05$ \\
\hline$\%$ Change & -5.9 & & 4.7 & & \\
\hline
\end{tabular}


As shown in Table 2, The average total cholesterol measured among Group A subjects at baseline period was $213.7 \pm 20.7 \mathrm{mg} / \mathrm{dl}$ which significantly increased by $1.8 \%$ by the end of $12^{\text {th }}$ week to $217.5 \pm 18.5 \mathrm{mg} / \mathrm{dl}$ whereas the average cholesterol measured among Group B subjects at baseline period was $211.4 \pm 20.8 \mathrm{mg} / \mathrm{dl}$ which significantly reduces by $7.9 \%$ to $194.6 \pm 12.6 \mathrm{mg} / \mathrm{dl}$ after 12 weeks therapy.

As shown in Table 3, The average HDL measured among Group A subjects at baseline period was $39.9 \pm 7.8 \mathrm{mg} / \mathrm{dl}$ which significantly reduces by $5.9 \%$ by the end of $12^{\text {th }}$ week to $37.6 \pm 6.7 \mathrm{mg} / \mathrm{dl}$ whereas the HDL levels measured among Group B subjects at baseline period was $39.6 \pm 7.9 \mathrm{mg} / \mathrm{dl}$ which significantly increased by $4.7 \%$ to $41.5 \pm 7.2 \mathrm{mg} / \mathrm{dl}$ after 12 weeks therapy.

As shown in Table 4, The average TG levels measured among Group A subjects at baseline period was $164.3 \pm 15.01 \mathrm{mg} / \mathrm{dl}$ which significantly increased by $12.4 \%$ by the end of 12 th week to $184.6 \pm 12.9 \mathrm{mg} / \mathrm{dl}$ whereas the average TG levels measured among Group B subjects at baseline period was $163.7 \pm 14.4 \mathrm{mg} / \mathrm{dl}$ which significantly reduces by $9.5 \%$ to $148.0 \pm 8.1 \mathrm{mg} / \mathrm{dl}$ after 12 weeks therapy.

Table 4: Comparison of triglyceride level of subjects ingroup A and group B.

\begin{tabular}{|llllll|}
\hline & Atenolol 50mg (group A) & Olmesartan $20 \mathrm{mg}$ (group B) & \multicolumn{1}{c|}{ T- Test } \\
(p- value in b/w groups)
\end{tabular}

Table 5: Comparison of Low Density Lipoprotein level of subjects ingroup A and group B.

\begin{tabular}{|c|c|c|c|c|c|}
\hline & \multicolumn{2}{|c|}{ Atenolol 50mg (group A) } & \multicolumn{2}{|c|}{ Olmesartan 20mg (group B) } & \multirow{2}{*}{$\begin{array}{l}\text { T- Test } \\
\text { (p- value in } b / w \text { groups) }\end{array}$} \\
\hline & Mean土SD & Paired T- Test p-value & Mean土SD & Paired T- Test p-value & \\
\hline Baseline & $140.9 \pm 25.4$ & \multirow{2}{*}{$<0.05$} & $139.0 \pm 21.8$ & \multirow{2}{*}{$<0.05$} & $>0.05$ \\
\hline Week 12 & $142.9 \pm 23.0$ & & $123.4 \pm 15.1$ & & $<0.05$ \\
\hline$\%$ Change & 1.5 & & -11.2 & & \\
\hline
\end{tabular}

As shown in Table 5, the average LDL levels measured among Group A subjects at baseline period was $140.9 \pm 25.4 \mathrm{mg} / \mathrm{dl}$ which significantly increased by $1.5 \%$ by the end of 12 thweek to $142.9 \pm 23.0 \mathrm{mg} / \mathrm{dl}$ whereas the average LDL measured among Group B subjects at baseline period was $139.0 \pm 21.8 \mathrm{mg} / \mathrm{dl}$ which significantly reduces by $11.2 \%$ to $123.4 \pm 15.1 \mathrm{mg} / \mathrm{dl}$ after 12 weeks therapy.

Table 6: Comparison of Very Low density Lipoprotein level of subjects in group A and group B.

\begin{tabular}{|c|c|c|c|c|c|}
\hline & \multicolumn{2}{|c|}{ Atenolol 50mg (Group A) } & \multicolumn{2}{|c|}{ Olmesartan 20mg (Group B) } & \multirow{2}{*}{$\begin{array}{l}\text { T- Test } \\
\text { (p- value in b/w groups) }\end{array}$} \\
\hline & Mean \pm SD & Paired T- Test p-value & Mean \pm SD & Paired T- Test p-value & \\
\hline Baseline & $32.8 \pm 3.0$ & \multirow{2}{*}{$<0.05$} & $32.7 \pm 2.8$ & \multirow{2}{*}{$<0.05$} & $>0.05$ \\
\hline Week 12 & $36.9 \pm 2.5$ & & $29.6 \pm 1.6$ & & $<0.05$ \\
\hline$\%$ Change & 12.4 & & -9.5 & & \\
\hline
\end{tabular}

As shown in Table 6, The average VLDL levels measured among Group A subjects at baseline period was $32.8 \pm 3.0 \mathrm{mg} / \mathrm{dl}$ which significantly increased by $12.4 \%$ by the end of $12^{\text {th }}$ week to $36.9 \pm 2.5 \mathrm{mg} / \mathrm{dl}$ whereas the average VLDL measured among Group B subjects at baseline period was $32.7 \pm 2.8 \mathrm{mg} / \mathrm{dl}$ which significantly reduces by $9.5 \%$ to $29.5 \pm 1.6 \mathrm{mg} / \mathrm{dl}$ after 12 weeks therapy.

\section{DISCUSSION}

The average cholesterol measured among Group A significantly increased by $1.8 \%$ at $12^{\text {th }}$ week. The average cholesterol in Group B significantly reduced by $7.9 \%$ by the $12^{\text {th }}$ week. Thus, present study demonstrates that there is increase of cholesterol after Atenolol therapy while there is decrease of cholesterol after Olmesartan therapy. But in 
another study conducted by Pollare $\mathrm{T}$ et al, in patients with primary HTN where they studied the effects of beta blockers viz Atenolol and Metoprolol on lipid metabolism; concluded that beta-selective blockade has no significant ( $p>0.001$ ) influence on total serum cholesterol levels. While our study demonstrates that Atenolol is significantly increasing cholesterol levels. ${ }^{9}$ Also Yilmaz MI et al conducted a study to evaluate the effect of antihypertensive agents on plasma adiponectin levels in hypertensive patients with metabolic syndrome as plasma adiponectin levels are well associate with metabolic syndrome. In this study patients were treated for 3 months with Atenolol $10 \mathrm{mg} /$ day and Valsartan $80 \mathrm{mg} /$ day. ${ }^{10}$ They showed that Valsartan increase the plasmaadiponectin levels significantly higher than other regimens ( $\mathrm{P}<0.05$ for both) while Atenolol did not make a significant effect. ${ }^{10}$ The plasma adiponectin levels were correlated with the total cholesterol ( $\mathrm{r}=-374, \mathrm{P}=0.002)$, high density lipoproteincholesterol $(\mathrm{r}=0.286, \mathrm{P}=0.005)$. But alteration in metabolic parameters with Valsartan, an ARB demonstrates that ARBs viz Olmesartan might have correlation with augmentation of metabolic parameters like serum cholesterol.

The average HDL measured among Group A significantly reduces by $5.9 \%$ by the $12^{\text {th }}$ week assessment, this corresponds with the similar comparable results obtained by Pollare $\mathrm{T}$ et al, in which they studied the effects of Atenolol and Metoprolol on lipid metabolism on 60 patients with primary HTN and concluded that HDL decreased by about $7 \%$, after administration of Atenolol on 60 patients with primary HTN. The average HDL measured among group B significantly incremented by $4.7 \%$ by the $12^{\text {th }}$ week assessment. When authors compared our results with Pollare $\mathrm{T}$ et al, study we concluded that although Atenolol has decreased HDL by $5.9 \%$, while Olmesartan has increased HDL by $4.7 \%$, but the decrease of HDL was more observed in Pollare et al study i.e. $7 \%$ after administration of Atenolol. ${ }^{9}$

The average TG levels measured among group A at baseline period significantly increased by $12.4 \%$ after the $12^{\text {th }}$ week assessment, the results of our study are similar to results obtained by Leren $P$ in which they reviewed the effects of Atenolol, Metoprolol, Propranolol on lipid metabolism and studied their lipid profile and concluded that Atenolol therapy significantly $(\mathrm{p}<0.001)$ increases serum TG levels by $25.8 \% .^{11}$ In group B patients, TG levels significantly reduce by $9.5 \%$ after 12 weeks therapy. When authors compared present results with Leren P study, authors concluded that although TG levels were increased by $12.4 \%$ with Atenolol, while TG levels were decreased by $9.5 \%$ with Olmesartan therapy, but there is greater increase in TG levels by $25.8 \%$ after Atenolol in Leren P study. ${ }^{11}$ Also the results of present study coincides with Galzerano D et al, in which various studies were reviewed to evaluate the antihypertensive efficacy and metabolic effects of Telmisartan, an ARB a congener of this widely prescribed drug category. ${ }^{12}$ In a study of 533 patients (with HCTZ added as needed to achieve BP control, the effects of Telmisartan on lipid parameters have also been observed in people with and without diabetes and were treated with Telmisartan 40 to $80 \mathrm{mg}$ for at least 1 year which led to reduction in triglycerides by $17.4 \mathrm{mg} / \mathrm{dL}$ and cholesterol by $16.4 \mathrm{mg} / \mathrm{dL}$ in the population as a whole and were $22.7 \mathrm{mg} / \mathrm{dL}$ and $23.8 \mathrm{mg} / \mathrm{dL}$, respectively, in patients with hypercholesterolemia. Thus, they concluded that Telmisartan is more efficacious, better tolerated than betablockers and have beneficial effects on metabolic parameters and these results are comparable with present results in lieu of greater reduction of TG by ARBs. ${ }^{12}$

In group A patients, LDL significantly increased by after 12 weeks treatment. In Group B patients, LDL significantly reduces by $11.2 \%$ after 12 weeks of therapy. The results of our study coincide with the study conducted by Fonseca VA which reviewed the pathophysiology of HTN and dyslipidemia as well as treatment effects from glucose- and lipid-lowering regimens on CVS. Based on a Pub Med literature search from January 1980 to December 2008, the effects of nonvasodilating (Atenolol) on parameters of glucose and lipid metabolism in HTN are studied which showed nonvasodilating beta-blockers are associated with a worsening of glycemic and lipid control. ${ }^{13}$

\section{CONCLUSION}

The present study concluded that Olmesartan medoxomil is a better drug for treating stage-1 HTN patients as compared to Atenolol, in general and especially in patients with dyslipidemia in view of greater reduction of total average cholesterol, TGs, LDL, VLDL and increase in HDL.

However, more such multicentric open/blind, studies on larger population with such disorders are required, so that this improved effectiveness in stage 1 HTN could be translated to maintain the target BP.

Funding: No funding sources

Conflict of interest: None declared

Ethical approval: The study was approved by the Institutional Ethics Committee

\section{REFERENCES}

1. Elkum N,Al-Arouj M, Sharifi M, Bennakhi A, Behbehani K, .Cardiovascular disease risk factors in the South Asian population :a cross-sectional study. Diabet Med. 2014 May; 31(5):531-9.

2. Stafylas PC, Sarafidis PA. Carvedilol in HTN treatment. Vasc Health Risk Manag. 2008 February; 4(1):23-30.

3. Chobanian AV, Bakris GL, Cushman WC, Black HR Green LA, Izzo JL et al. Seventh report of the joint national committee on prevention, detection, evaluation, and treatment of high blood pressure: the JNC report. JAMA. 2003;289(19):2560-72.

4. Bundgaard M, Jarbol DE, Paulsen MS, Jacobsen JL, Pedersen ML. Prevalence of the use of 
antihypertensive medications in Greenland: a study of quality of care amongst patients treated with antihypertensive drugs. Int $\mathbf{J}$ Circumpolar Health. 2012;71:10.3402.

5. Lawes CM, Vander Hoorn S, Rodgers A. Global burden of blood-pressure-related disease, 2001. Lancet. 2008 May 3;371(9623):1513-8.

6. Carretero OA, Oparil S. Essential hypertension: part I: definition and etiology. Circulation. 2000 Jan 25;101(3):329-35.

7. Gupta R. Trends in hypertension epidemiology in India. J Hum Hypertens. 2004 February;18(2):73-8.

8. James PA, Oparil S, Carter BL, Cushman WC, Dennison-Himmelfarb C, Handler J, et al. 2014 evidence-based guideline for the management of high blood pressure in adults: report from the panel members appointed to the Eighth Joint National Committee (JNC 8). JAMA. 2014 Feb 5;311(5):50720.

9. Pollare T, Lithell H, Selinus I, Berne C. Sensitivity to insulin during treatment with atenolol and metoprolol: a randomised, double blind study of effects on carbohydrate and lipoprotein metabolism in hypertensive patients. $\mathrm{Br}$ Med J. 1989 Apr 29;298(6681):1152-7.
10. Yilmaz MI, Sonmez A, Caglar K, Celik T, Yenicesu M, Eyileten T, et al. Effect of antihypertensive agents on plasma adiponectin levels in hypertensive patients with metabolic syndrome. Nephrology. 2007 Apr 1;12(2):147-53.

11. Leren P. Comparison of effects on lipid metabolism of antihypertensive drugs with alpha- and betaadrenergic antagonist properties. Am J Med. 1987 Jan 5;82(1A):31-5.

12. Galzerano D, Capogrosso C, Di Michele S, Galzerano A, Paparello P, Lama D, et al. New standards in hypertension and cardiovascular risk management: focus on telmisartan. Vascular health and risk management. 2010;6:113-33.

13. Fonseca VA. Effects of $\beta$-blockers on glucose and lipid metabolism. Current Med Res Opin. 2010 Mar 1;26(3):615-29.

Cite this article as: Singh RJ, Kohli K, Gupta P, Gupta AK. Monitoring effects of atenolol versus olmesartan medoxomil on metabolic parameters. Int J Basic Clin Pharmacol 2018;7:1837-41. 